Lessing and Marmontel

Author(s): J. G. Robertson

Source: The Modern Language Review, Vol. 6, No. 2 (Apr., 1911), pp. 216-218

Published by: Modern Humanities Research Association

Stable URL: http://www.jstor.org/stable/3713403

Accessed: 05-01-2016 10:54 UTC

Your use of the JSTOR archive indicates your acceptance of the Terms \& Conditions of Use, available at http://www.jstor.org/page/ info/about/policies/terms.jsp

JSTOR is a not-for-profit service that helps scholars, researchers, and students discover, use, and build upon a wide range of content in a trusted digital archive. We use information technology and tools to increase productivity and facilitate new forms of scholarship. For more information about JSTOR, please contact support@jstor.org. 
in a note of Gibbon's to his account of John Hawkwood in Chapter LXV I of the Decline and Fall:

'After two-and-twenty victories, and one defeat, Hawkwood died, in 1394, general of the Florentines, and was buried with such honours as the republic has not paid to Dante or Petrarch' (ed. cit. vol. vil, pp. 211-12).

The second reference, which occurs in Gibbon's Antiquities of the House of Brunswick (1790), is of special interest, as showing that he was acquainted with Dante's De Vulgari Eloquentia, a treatise with which Gray was well acquainted, and of which Tyrwhitt, the editor of Chaucer, and Thomas Warton, had some knowledge, but which was otherwise apparently almost unknown in England in the eighteenth century. In the passage in question Gibbon writes:

'The father of the Tuscan muses, the sublime but unequal Dante, had pronounced that Ferrara was never honoured with the name of a poet' (Miscellaneous Works, ed. 1796, vol. II, p. 693).

Dante's statement occurs in the first book of the treatise:

'Ferrariensium...nullum invenimus poetasse' ( $V$. E., I. 15, 1l. 21-2).

Fiveways, Burnham, Bucks.

Paget ToynbeE.

\section{LESSing AND MARMONTEL.}

Notwithstanding the careful investigations that have already been made into the sources of Lessing's Laokoon, more especially those of H. Blümner in his edition of that work (2nd edition, Berlin, 1880)1, there is still something to be done in laying bare what might be called the 'literary' sources and antecedents of that work, as opposed to those dealing in the first instance with the theory of painting and sculpture, to which investigators have hitherto chiefly directed their attention. As far as I am aware, no one has yet noticed the remarkable anticipation of Lessing's theories in Marmontel's Poétique Françoise, which appeared in two volumes at Paris, in 1763. This book was well-known in Germany; a long review of it with a copious summary of its contents, appeared in the Bibliothek der schönen Wissenschaften und der freien Künste, Vol. XI, i, pp. 13 ff., ii, pp. 289 ff. and Vol. XII, i, pp. $42 \mathrm{ff}$. (1764-65), and it was translated into German by B. von Schirach,

1 The English reader will find the matter excellently discussed by Professor W. G. Howard in his recent edition : Laokoon, Lessing, Herder, Goethe. Selections edited with an Introduction and a Commentary. New York, 1910. 
Bremen, 1765-66. It did not, of course, escape Lessing's notice; he quotes the second volume in Section XVII of the Laokoon, and translates a passage from it in the fourteenth number of his Hamburgische Dramaturgie.

The following passages have, as will be seen, a very immediate bearing on the main problem of the Laokoon:

Vol. I, p. 39: Si je dis, comme Simonide, que la Peinture est une Poësie muette, je crois la definir complettement; si je dis que la Poësie est une peinture animée et parlante, aurium pictura, je suis encore bien au-dessous de l'idée qu'on en doit avoir.

Pp. 40 f. : La Peinture saisit son objet en action, mais ne le présente jamais qu'en repos. En exprimant ces vers de Virgile:

Illa vel intactae segetis per summa volaret

Gramina, nec teneras cursu laesisset aristas,

le Peintre représentera Camille élancée sur la pointe des épis, mais immobile dans cette attitude; au lieu qu'en Poësie l'imitation est progressive et aussi rapide que l'action même. La Poësie n'est donc plus le tableau, mais le miroir de la Nature.

Dans un miroir les objets se succedent et s'effacent l'un l'autre; la Poësie est comme un fleuve qui serpente dans les campagnes, et qui dans son cours répete à la fois tous les objets répandus sur ses bords. Il y a plus: cet espace que parcourt la Poësie est dans l'étendue successive comme dans l'étendue permanente: ainsi le même vers présente à l'esprit deux images incompatibles, les étoiles et l'aurore, le présent et le passé:

Jamque rubescebat stellis aurora fugatis.

Dans les exemples du tableau du miroir et du fleuve, on ne voit qu'une surface; la Poësie tourne autour de son objet comme la Sculpture, et le présente dans tous les sens.

P. 85 : Le tableau superficiel de la Nature est lui seul d'une richesse, d'une variété, d'une étendue à occuper des siècles d'étude. Mais tous les détails n'en sont pas favorables à la Poësie; tous les genres de Poësie ne sont pas susceptibles des mêmes détails. Ainsi le Poëte n'est pas obligé de suivre les pas du Naturaliste.

P. 169: La mort de Laocoon dans l'Énéide est un tableau; l'incendie de Troye est une description; la description differe du tableau, en ce que le tableau n'a qu'un moment et qu'un lieu fixe. La description peut être une suite de tableaux; le tableau peut être un tissu d'images; l'image elle-même peut former un tableau: nous en allons voir des 
exemples. Mais l'image, comme je l'ai définie, est le voile matériel d'une idée; au lieu que la description et le tableau ne sont le plus souvent que le miroir de l'objet même.

P. 342: Aussi la Peinture et la Sculpture préferent-elles la Nature en repos à la Nature en mouvement, et cependant elles n'ont jamais qu'un moment à saisir et à rendre; au lieu que la Poësie doit pouvoir suivre la Nature dans ses progrès les plus insensibles, dans ses mouvements les plus rapides, dans ses détours les plus secrets.

Pp. 349 f.: Or les vues dans lesquelles opere la Poësie ne sont pas celles de la Nature: la bonté, la beauté poëtique n'est donc pas la bonté, la beauté naturelle. Ce qui même est beau pour un Art peut ne l'être pas pour les autres: la beauté du Peintre ou du Statuaire, peut être ou n'être pas celle du Poëte, et réciproquement, selon l'effet qu'ils veulent produire. Enfin ce qui fait beauté dans un Poëme, ou dans tel endroit d'un Poëme, devient un défaut, même en Poësie, dès qu'on le déplace et qu'on l'employe mal-à-propos.

These passages are, I think, of sufficient interest to warrant their being reprinted here, more especially as the Poétique Françoise is not included, in its original form, in editions of Marmontel's works, and is consequently not easily accessible. It might be rash to claim for the passages the importance of being immediate sources for the Laokoon: but a certain suggestive value they undoubtedly had for a mind so keenly receptive towards the ideas of his contemporaries as Lessing's was. Marmontel had probably more understanding than any other of Lessing's predecessors in this field for the peculiar problems which Lessing set himself to solve. Although there is no attempt in the French work to limit the sphere of the poet as regards allegorical and descriptive poetry, such limitation was a reasonable inference from the suggestions thrown out in the two last of the passages quoted.

J. G. Robertson.

LoNDON. 